Est Ag 52 (2017) 489-530

\title{
La misa y la pasión
}

\section{LUIS RESINES LLORENTE}

RESUMEN: Un catecismo del siglo XVIII muestra un singular paralelismo entre los ritos de la misa y la pasión de Jesús, y proporciona a cada gesto o rito una significación alegórica, completamente arbitraria. A finales del XIX se mantuvo e incluso se amplió con la idea de reproducir cada uno de los detalles, reales o imaginarios, de la pasión. Es una forma exagerada de reforzar el aspecto de sacrificio, según la doctrina de Trento.

PalabRas Clave: Misa, pasión, sacrificio, rito, liturgia.

ABSTRACT: A text of catechism from XVIIIth century shows a singular parallelism between the rites of the mass and the passion and sufferings of Jesus. It refers each rite with an allegoric signification. It remains until the end of XIXth century, when it was more increased with very many details, seeing the sacrificial aspect of the mass, according the teaching of Trent council.

KEYwORDs: Mass, passion, sacrifice, rite, liturgy.

Un raro y -por lo que sé- único ejemplar de catecismo que hace tiempo llegó a mis manos estaba esperando su momento para hacer un comentario sobre él.

Es una de esas ocasiones en que la catequesis, que ha de presentar los misterios de la fe, deriva hacia la liturgia, puesto que resulta inevitable que este aspecto ha de ser ofrecido al creyente, a fin de que sepa captar adecuadamente cuanto está relacionado con los sacramentos, principalmente.

Pero en esta ocasión, no se trata de la liturgia propiamente dicha, sino de un aspecto muy particular y concreto, como es el de la misa; e incluso ésta ceñida a un enfoque como es la de considerarla desde el punto de vista sacrificial, $y$, por consiguiente, vinculada de forma minuciosa a la pasión de Jesús. 
Adelantado este primer esbozo, procede describir el catecismo en cuestión. Se trata de un ejemplar falto de portada, y consiguientemente de cualquier indicación que pudiera aportar algo más de precisión sobre el autor, título, fecha, lugar de publicación, imprenta o cualquier otro vestigio. Sin embargo el papel en que está impreso y el tipo de impresión permiten situarlo con bastante certeza en la segunda mitad del XVIII. El dato está corroborado porque en una de las oraciones de la segunda parte, el "ofrecimiento de la misa", se elevan súplicas a Dios "por la salud e intención más perfecta de nuestro Católico Rey Carlos Tercero y por toda la Prole Regia...”. Esta frase permite enmarcar la obra entre los años 1759 (acceso de Carlos III) y 1788 (muerte del rey). La fecha inicial (1759) aun aparece más evidente, puesto que no se incluye en las súplicas la figura de la reina, María Amalia de Sajonia, fallecida el 27 de septiembre de 1759, con la que Carlos III tuvo siete hijos y seis hijas; pedir sólo por la descendencia real supone ya el fallecimiento de su esposa.

En formato $8^{\circ}(100 \times 72 \mathrm{~mm})$, consta de un único cuadernillo que tendría que ser de 14 hojas (28 páginas), pero, como está indicado, le falta la hoja primera (páginas 1 y 2). Tiene adicionada una encuadernación posterior, aunque no demasiado tardía, que consiste en un cartoncillo a la medida, coloreado en azul verdoso con un dibujo geométrico, más unas guardas igualmente coloreadas en tonos rojizos oscuros. El cuadernillo y el cartón que le sirve de protección están cosidos con hilo, anudado en las páginas centrales. Además, la que constituye página $28^{\mathrm{a}}$, no numerada, en blanco, está pegada a un papel de refuerzo, quizá antes de que se añadiera el cartón que le sirve de encuadernación protectora. Acaso pudo ser entonces cuando se perdió la hoja primera (páginas 1-2), y con ella cualquier información. En la página $3^{\mathrm{a}}$ aparece una rara signatura: $\mathrm{A}^{3}$, la única que figura, que no corresponde a nada, puesto que el impreso tampoco está constituido por un cuadernillo de seis hojas, de la que ésta constituyera la mitad. Y no hay ninguna otra signatura, lo que hace más extraña la presencia de ésta.

Descrito el ejemplar, anotaré que le he proporcionado el supuesto título de Catecismo sobre la misa, que encaja con la enseñanza que presenta. Procede, pues, pasar a examinar su contenido. El Catecismo sobre la misa tiene dos partes claras: una primera interrogativa, que abarca las páginas 3-16; y una segunda, consistente en explicaciones, que va desde la p. 17 a 27.

Prefiero comenzar la descripción por la parte segunda, para no interrumpir el hilo del discurso de la parte primera, motivo central de este 
trabajo. Esta segunda parte consiste en una serie de oraciones y de recomendaciones centradas en la misa, la confesión y comunión:

- ofrecimiento de la misa (p. 17-18)

- consejo de oír misa como preparación para la confesión (p. 18-20)

- consejos previos a la confesión (p. 20-21)

- oración a nuestra Señora para antes de la confesión (p. 21-22)

- consejos para el acto de la confesión (p. 22-23)

- oración para después de la confesión (p. 23-25)

- oración para antes de comulgar (p. 25-26)

- oración para después de la sagrada comunión (p. 26-27). Al final, "Laus Deo".

Es posible apreciar cómo se sirve de la misa, ya que ésta es entendida como una preparación para la confesión y posterior comunión: esto último es lo verdaderamente importante, y la misa tiene la virtud de crear el clima posible para que confesión y comunión se lleven a cabo de la mejor forma posible.

De ahí que el lector de este Catecismo sobre la misa, una vez instruido con la primera parte sobre lo que significan al detalle cada una de sus partes en particular, podía estar en la misa con las consideraciones que se le ofrecían, para, de esta forma piadosa, acercarse a la confesión y comunión; esta última, por descontado, no tenía lugar en el transcurso de la propia celebración, sino en otro momento distinto.

He titulado el segundo apartado como "consejos previos a la confesión", por diferenciarlo del cuarto, titulado como "consejos para el acto de la confesión". La realidad es que se trata de una duplicación, porque tanto en uno como en otro caso recomienda el texto que se ponga a los pies del confesor, con humildad, exprese sus pecados y reciba la absolución. Ahora bien, el autor del Catecismo sobre la misa no tuvo inconveniente en proponer dos veces las cosas, como redundancia, ya que ello no iría en perjuicio del penitente.

Es preciso volver, por tanto, a la primera parte, la constituida por el interrogatorio, o catecismo y que en cierto modo es tenido en consideración en los consejos y oraciones de la parte segunda.

La parte primera carece de epígrafe propio, y se abre directamente con las preguntas y sus correspondientes respuestas. Tampoco hay división interna alguna que permita agruparlas en diversos apartados, aunque, como se verá, sí se puerden perfilar dos bloques bien definidos, uno 
que se refiere a los elementos indispensables para la celebración, junto con su interpretación simbólica; y otro, que sigue el decurso de la misa, asignando significados, y motivos de reflexión igualmente simbólicos.

Antes de entrar en materia, es preciso hacer una advertencia, absolutamente indispensable, pero que no consta en el texto. Aparecen 69 preguntas, pero de ellas, las tres primeras, y las cuatro últimas están literalmente copiadas del conocido como catecismo de Ripalda, aunque hoy resulte plenamente seguro y sabido que quien realmente lo escribió fue Gaspar Astete, si bien figure a nombre de su compañero jesuita.

Lo que en realidad sucede en este Catecismo sobre la misa es algo muy similar a lo que encontramos en el libro de Job: a una historia precedente, un cuentecillo con final moralizante, se le interrumpe para insertar una serie de reflexiones; y se hace con habilidad, para que, quien no conozca el mecanismo utilizado, no descubra la interpolación y lo lea como texto seguido, sin interrupciones. En el caso presente, se produce igualmente una interpolación hábil entre las preguntas que procedían de Astete (segundo catecismo), de manera que quien no lo descubra, lea el texto como si se tratara de algo unitario:

\begin{tabular}{l|l|l}
\hline $\begin{array}{l}3 \text { primeras preguntas } \\
\text { de Astete (Ripalda) }\end{array}$ & $\begin{array}{l}62 \text { preguntas interca- } \\
\text { ladas, sobre la consi- } \\
\text { deración de la pasión }\end{array}$ & $\begin{array}{c}4 \text { últimas preguntas } \\
\text { de Astete (Ripalda) }\end{array}$
\end{tabular}

El hecho de no ser un texto muy largo, y, por otra parte, resultar muy escasamente conocido, permite su reproducción íntegra:

(1) P. ¿Qué cosa es Misa?

R. Un Sacrificio que se hace de Cristo y una representación de su vida y muerte.

(2) P. ¿A quién se hace este Divino Sacrificio?

R. Al Eterno Padre.

(3) P. ¿Para qué?

R. Para tres fines: para darle gracias, satisfacerle y pedirle beneficios.

(4) P. ¿Cuántas cosas son precisas para celebrar este Divino sacrificio? 
R. Diez y ocho, en sí muy distintas.

(5) P. ¿Cuáles son?

R. El Sacerdote, el Ministro, el Amito, la Alba, y el Cíngulo, la Estola, el Manípulo, la Casulla, el Cáliz Consagrado, el Purificador, la Patena, la Hostia, la Hijuela, el Paño que cubre el Cáliz, un Misal, Vinageras, con Agua y Vino, dos luces, una Cruz y un Altar.

(6) P. ¿Qué significa el Sacerdote?

R. Representa a Cristo.

(7) P. ¿Y el Ministro?

R. A los Ángeles que le asistían.

(8) P. ¿Qué significa el Amito?

R. El Velo con que vendaron a Cristo los Ojos y su Santísimo Rostro.

(9) P. ¿Qué significa el Alba?

R. Aquella vestidura blanca que por escarnio pusieron a Cristo en casa de Herodes.

(10) P. ¿Qué significa el Cíngulo?

R. La soga con que en el Huerto fue atado

(11) P. ¿Y el Manípulo?

R. Significa los Cordeles con que fue amarrado a la Columna.

(12) P. ¿Qué significa la Estola?

R. Aquella soga con que fue llevado Cristo a crucificar, tirándole de ella, puesta al cuello.

(13) P. La Casulla, ¿qué significa?

R. A la púrpura vieja y rota que por escarnio vistieron a Cristo en casa de Pilato.

(14) P. ¿La Corona de Espinas que pusieron a Cristo, en qué se nos da a entender?

R. En la que lleva figurada el Sacerdote en su propia cabeza.

(15) P. ¿Una Cruz que vemos en la Casulla, qué representa?

R. Aquella que llevó en sus santísimos hombros Cristo nuestro bien, en la que dio la vida por nosotros.

(16) P. ¿Qué significa el Cáliz?

$\mathrm{R}$. Aquel en que consagró el Señor la noche de la Cena

(17) P. ¿Y la patena, qué significa?

R. Aquella losa que pusieron los Judíos en el Sepulcro de Cristo.

(18) P. ¿Qué significa la Hostia por consagrar?

R. Aquel Pan que Cristo consagró en la última Cena. 
(19) P. El Paño o Velo que cubre el Cáliz y los corporales, ¿qué significan?

R. Aquellos Lienzos en que fue envuelto el Cuerpo difunto de Cristo.

(20) P. ¿Qué significa el Altar con la Cruz?

R. El Monte Calvario.

(21) P. ¿Las Velas encendidas, qué significan?

R. La humildad, devoción, reverencia y fervor con que debemos estar a la contemplación del Divino Sacrificio de la Misa.

(22) P. ¿Podremos, según el orden de la Misa, considerar en la Pasión de Cristo?

R. Sí, y con mucho fruto de nuestras almas, y del prójimo.

(23) P. ¿Qué beneficio lograrán nuestras Almas por medio de esta consideración?

R. Un deseo firmísimo de amar a Dios, y un aborrecimiento total de la culpa.

(24) P. ¿Qué provecho para el prójimo?

R. Amarlo en Dios, socorrerlo en todas sus necesidades.

(25) P. Pues siendo así, decidme, ¿qué debemos considerar mientras el Sacerdote sale al Altar?

R. La última Cena, en que fue instituido tan alto y Divino sacrificio.

(26) P. ¿Cuando va el Sacerdote al Altar, qué se considera?

R. La presteza y diligencia con que Cristo fue a Orar al Huerto con los Apóstoles.

(27) P. ¿Y al principio de la Misa?

R. La Oración que tres veces hizo Cristo en el Huerto.

(28) P. ¿Qué hemos de considerar en la confesión?

R. Las agonías y sudor de sangre que padeció Cristo.

(29) P. ¿Al besar el sacerdote el altar, qué se ha de considerar?

R. Aquel falso beso que por señal dio Judas a Cristo para que los Judíos le prendiesen.

(30) P. ¿Al ir el Sacerdote al lado de la Epístola?

R. Considerar la prisión de Cristo y tropa con que llevaron a Cristo.

(31) P. ¿Y al Introito de la Misa?

R. El Examen que hizo Anás del mismo Cristo.

(32) P. ¿Qué se ha de considerar a los Kyries?

R. Las tres negaciones de San Pedro. 
(33) P. ¿A la Gloria, qué se ha de considerar?

R. La alegría que los Judíos tenían de las penas y tormentos que padecía Cristo nuestro bien.

(34) P. ¿Y al Dominus vobiscum?

R. Cuando Cristo volvió su Divino Rostro para mirar a San Pedro.

(35) P. En las primeras oraciones, ¿qué hemos de considerar?

R. Las acusaciones, afrentas, desprecios, bofetadas y salivas que recibió Cristo en casa de Caifás.

(36) P. ¿Y cuando se lee la Epístola?

R. Considerar cuando Cristo fue llevado a casa de Pilato.

(37) P. ¿ $\mathrm{Y}$ al ir el Sacerdote al medio del Altar?

R. Cuando Cristo fue llevado desde casa de Pilato a la de Herodes.

(38) P. ¿Qué hemos de considerar en leyendo el primer Evangelio?

R. La Doctrina que nos enseñó Cristo, y el examen que de sus obras segunda vez hizo Pilato.

(39) P. ¿Y cuando se descubre el Cáliz?

R. Considerar cómo Cristo fue despojado de sus Sagradas vestiduras para ser amarrado a la Columna y rigurosamente azotado.

(40) P. ¿Y al ofertorio de la Hostia?

R. Aquellos rigurosos azotes que impíamente descargaron sobre el venerabilísimo Cuerpo de Cristo.

(41) P. Al cubrir el sacerdote el cáliz, ¿qué se ha de considerar?

R. Cuando pusieron la agudísima y cruel Corona de Espinas en la Santísima Cabeza de Cristo.

(42) P. ¿Y al lavarse el Sacerdote, qué se considera?

R. El lavatorio de Pilato.

(43) P. ¿El Orate fratres?

R. Considerar cuando Cristo fue puesto en la Ventana de la casa de Pilato a la vista de todo el pueblo y les dijo: Ecce Homo.

(44) P. ¿Qué se considera al Prefacio?

R. Cómo el Pueblo, no contento con lo que Cristo había padecido, voceó pidiendo que lo crucificasen.

(45) P. ¿Y al Canon o Santus?

R. Considerar la humildad con que Cristo cargó sobre sus benditísimos hombros la pesada cruz de nuestras culpas.

(46) P. ¿Y al tocar la Campanilla tres veces? 
R. Considerar el ruido de roncas Trompetas y Tambores, y los Pregones que decían llevando a Cristo a crucificar.

(47) P. ¿Qué se ha de considerar a la elevación de la Hostia?

R. Cómo Cristo, después de crucificado, fue levantado en el alto a la vista de todo el Pueblo.

(48) P. ¿Y qué significa el tomar el sacerdote la Hostia con dos dedos?

R. El haber sido crucificado Cristo en medio de dos ladrones.

(49) P. ¿Y al elevar el cáliz?

R. Considerar en la preciosísima sangre que derramó Cristo en la Cruz.

(50) P. ¿Qué hemos de considerar al Memento por los difuntos?

R. Cómo Cristo rogó al Eterno Padre por el Género humano.

(51) P. ¿Y al hacer el Sacerdote aquellas cinco Cruces sobre el Cáliz y la Hostia?

R. Se ha de considerar en las cinco llagas de Cristo.

(52) P. ¿Y cuando el Sacerdote se da un golpe en el pecho?

R. El perdonar Cristo a aquellos que le crucificaron.

(53) P. ¿Y al Alzar la Hostia con el Cáliz?

R. Considerar la hiel y el vinagre que dieron a Cristo.

(54) P. ¿Y al decir el Sacerdote el pater noster?

R. Se considera aquellas siete palabras que habló Cristo en la cruz.

(55) P. ¿Qué se considera al partir el Sacerdote la Hostia?

R. Aquella voz que dio el Señor cuando murió.

(56) P. ¿Al poner el Sacerdote una parte de la Hostia en el Cáliz, qué se ha de considerar?

R. El descendimiento de Cristo al Seno o Lugar de los Santos padres.

(57) P. ¿Y al decir el Sacerdote tres veces Agnus Dei?

R. Considerar la conversión de muchos que crucificaron a Cristo.

(58) P. ¿Qué se considera cuando el Sacerdote comulga?

R. El entierro que los Santos Varones hicieron al cuerpo difunto de Cristo.

(59) P. ¿Y cuando el Sacerdote cubre el Cáliz?

R. La losa que los Judíos pusieron en el Sepulcro de Cristo.

(60) P. ¿Y al ir el sacerdote al lado de la Epístola?

$\mathrm{R}$. La resurrección de Jesucristo. 
(61) P. ¿Y al Dominus vobiscum?

R. La aparición de Cristo a sus Apóstoles.

(62) P. A las últimas oraciones, ¿qué se ha de considerar?

R. Aquel tiempo que estuvo Cristo en esta vida después de resucitado con los Apóstoles.

(63) P. ¿Al último Dominus vobiscum?

R. La Ascensión del Señor.

(64) P. ¿Qué se considera cuando el Sacerdote echa la Bendición?

R. La venida del Espíritu Santo sobre el Apostólico colegio.

(65) P. ¿Y al último Evangelio?

R. La predicación que de Cristo y su admirable doctrina hicieron por todo el mundo los Apóstoles.

(66) P. ¿A quién aprovechan las Misas?

R. A los vivos y difuntos del purgatorio.

(67) P. Y de éstos, ¿a cuáles más principalmente?

R. Aquellos por quienes se dicen, las oyen y ofrecen.

(68) P. ¿Quién cumple con el precepto de oír Misa entera?

R. Quien asiste a toda ella sin distraerse de su voluntad.

(69) P. ¿Quién esta desobligado de oírla?

R. Quien con verdadera necesidad está impedido.

Resulta inevitable tener que hacer un comentario a lo que sugiere y enseña el cuestionario reproducido, ya que el acceso a los textos es incompleto si no se procede a su valoración.

El cuestionario de este Catecismo sobre la misa consta de 69 preguntas en total. De ellas, hay que dejar de lado las que proceden del catecismo de Astete, antes conocido como Ripalda (las tres primeras y las cuatro últimas). Las 62 preguntas restantes se pueden agrupar casi espontáneamente en dos secciones: una que abarca las preguntas $4^{\mathrm{a}}$ a $21^{\mathrm{a}}$, que se centra en las personas, y a renglón seguido en los instrumentos que hacen falta para la celebración; y otra segunda sección (preguntas $22^{\mathrm{a}}$ a $65^{2}$ ) que lleva a cabo una trasposición al hilo del desarrollo de la misa.

\section{SeCCión $1^{\mathrm{a}}$ - Personas E InSTRUMentos}

Las preguntas $4^{\mathrm{a}}$ y $5^{\mathrm{a}}$, conectadas, hablan de las diez y ocho cosas necesarias para la celebración. Entre las "cosas" están las personas del sacerdote y del ayudante o ministro. La enumeración de los diez y ocho 
requisitos indispensables no deja cabo suelto. Y aunque no menciona los corporales, aparecen éstos en la pregunta $19^{\mathrm{a}}$, de manera que no se puede hablar de omisión. No aparecen otros instrumentos como, por ejemplo, las sacras, que no resultaban absolutamente indispensables, aunque sí recomendadas.

Podría decirse que esta sección primera goza de una autonomía plena, así como de sentido propio. De tal manera que, de concluir la exposición con la pregunta $21^{a}$, no se echarían de menos el resto de las preguntas de la sección segunda, pues la primera tiene sentido por sí misma.

Se da una asignación de significados a los instrumentos que resulta totalmente arbitraria, a fin de guardar un cierto paralelismo con el desarrollo de la pasión, en sus grandes líneas. Sin embargo, no hay más remedio que reconocer que algunos de esos significados son forzados, como el de la pregunta $7^{\mathrm{a}}$, que identifica al ayudante con los ángeles que asisten a Cristo. Éste es identificado con el celebrante (pregunta $6^{\mathrm{a}}$ ), pero no hay en ello una especial consideración teológica, sino algo mucho más simple: la referencia a Cristo de todo cuanto el sacerdote realiza en la misa, para poder de este modo establecer un paralelo con la pasión. Por descontado, el resto de los participantes de la misa, casi se difuminan en contraste con la figura de Cristo, y la de aquellos que, según el relato evangélico, tomaron parte activa en el decurso de la pasión. Sólo aparecen los asistentes a la misa -aún está lejano el criterio del Vaticano II de "participantes"aludidos en sus actitudes en la pregunta $21^{\text {a }}$ por las velas encendidas (?), a los que el autor del Catecismo invita a asistir con fervor y devoción, dada la importancia de lo que se celebra.

Si la anterior asignación de significado está forzada, lo mismo cabe decir de la pregunta $14^{\mathrm{a}}$, en que se identifica la corona de espinas, con la coronilla o tonsura clerical, habitual, que identificaba al sacerdote, pero no sólo a la hora de la celebración, sino en todo momento.

Hay algunos otros comentarios que hacer. Por ejemplo, el hecho de que la estola se colocara al cuello lleva al autor a suponer una soga al cuello de Cristo para conducirlo a la muerte, de la que nada dice el evangelio, pero que da por supuesta como un hecho indiscutible (aunque en la realidad viva de los hechos fuera muy probable). También introduce otra calificación al proponer como significado de la casulla la púrpura "vieja y rota" puesta por escarnio por los soldados romanos. El evangelio nada dice de esta doble condición que aparece aquí como indiscutible y puramente imaginaria. La pregunta $15^{\mathrm{a}}$ se refiere al adorno habitual de 
las casullas más sencillas, que era una cruz (no siempre en las casullas de lujo, mucho más llamativas): es la oportunidad aprovechada por el autor del Catecismo para aludir a la cruz que Cristo llevó.

Al cáliz le asigna el sentido de sepulcro, y a la patena, puesta sobre él, el de la losa que lo cerraba por la parte superior (Nada se dice de la cavidad excavada, en la que las mujeres penetraron en la mañana de resurrección: Lc. 24, 3; o Pedro y Juan: Jn. 20, 8). Resulta sorprendente que en la pregunta $18^{\mathrm{a}}$ se haga referencia al pan, y no se diga nada del vino, a pesar de que lo ha señalado como elemento indispensable en la enumeración primera. Algo semejante ocurre con la hijuela, incluida en la lista de lo necesario, pero de la que no se vuelve a hablar.

El paralelo con la pasión, como he indicado, podría darse por completo, dentro de lo forzado de las asignaciones, para evocar algunos pasajes de la pasión, aunque no estuvieran todos. Esta práctica resulta habitual, por ejemplo, en el vía crucis, que resalta algunos momentos, a los que se añaden otros no incluidos en los relatos evangélicos. Por eso manifesté que el cuestionario se podría dar por concluido con la pregunta $21^{\mathrm{a}}$. Pero el deseo de una exposición más completa, minuciosa, al hilo de los acontecimientos, da paso a las preguntas de la sección segunda.

\section{SECCIÓN $2^{\mathrm{a}}$ - ACONTECIMIENTOS DE LA PASIÓN}

Las preguntas de esta sección (desde la $22^{\mathrm{a}}$ hasta la $65^{\mathrm{a}}$ ) van marcando los diversos pasajes que nos transmiten los evangelios con el mismo orden que allí aparecen. El discurrir de la misa es un perfecto paralelo del discurrir de la pasión, aunque para ello haya que forzar los significados en ciertos momentos, o ante ciertas ceremonias litúrgicas. Pero esto no preocupa al autor del Catecismo sobre la misa, cuya intención de establecer y mantener este paralelismo es evidente.

A la pregunta $22^{\mathrm{a}}$, que da inicio a la sección segunda, siguen otras dos que se centran en el provecho que se sigue para uno mismo y para el prójimo al hacer semejante consideración o reflexión sobre la misa; en ambos casos aparece en primer lugar el deseo de amar a Dios, pero la diferencia es que para la persona que hace esta reflexión le sirve, además, de aborrecimiento de sus culpas, mientras que respecto del prójimo resalta el servicio y atención en sus necesidades.

La pregunta $25^{\mathrm{a}}$ comienza la exposición simbólica de cada uno de los pasos de la misa. Y puede haber un cierto equívoco, porque en esta pre- 
gunta $25^{\text {a }}$ se interesa por el significado del sacerdote que "sale", en tanto que en la siguiente se interesa por cuando "va". Es claro que la pregunta $25^{\mathrm{a}}$ se refiere al trayecto desde la sacristía, mientras que la $26^{\mathrm{a}}$ pone la atención en cuando "llega" al altar, finalizado ese recorrido. A la pregunta $25^{\mathrm{a}}$ le asigna el simbolismo de la última cena, y a la pregunta $26^{\mathrm{a}}$, el de oración en el huerto de los olivos. Resulta forzado entender que las oraciones al pie del altar se identifiquen con la oración en el huerto; por el contrario, el respetuoso beso al altar es incuestionablemente identificado con el beso de Judas para completar la entrega (pregunta 29a); la ocasión es aprovechada, aunque el significado real del rito nada tenga que ver con el propuesto: la veneración que en ese momento hacía el sacerdote aludía a las reliquias depositadas en el ara del altar.

La pregunta $30^{\mathrm{a}}$, y la siguiente casi forman una unidad, pues el sacerdote se dirigía al lado derecho del altar para leer el introito. Desdoblada en dos interrogaciones, una alude a la prisión de Cristo, y la otra al interrogatorio de Anás. Es claro que no hay punto de contacto, pero el desarrollo de la narración así lo requería. A la recitación de los kyries se asocia la triple negación de Pedro, por el hecho de que los kyries entrañan una triple recitación (pregunta $32^{\mathrm{a}}$ ). La proclamación gozosa del gloria resulta enteramente trastocada, para ver en ella el gozo de los enemigos de Cristo ante su detención y posible desenlace (pregunta 33a). Sigue el "Dominus vobiscum" (pregunta 34 ) que aparece tres veces en el decurso de las explicaciones (esta pregunta, más las preguntas $61^{\mathrm{a}}$ y $63^{\mathrm{a}}$ ): en cada uno de los tres casos se le asigna a la expresión un sentido diverso, acomodado al desarrollo de los hechos, y no a cuanto pudiera encontrarse en el saludo ritual. En esta ocasión se evoca que Cristo volvió su rostro a Pedro tras las negaciones, que habían aparecido en la pregunta $32^{\mathrm{a}}$.

Dada la fácil y gratuita imaginación para conectar ritos y hechos, extrañan las preguntas $36^{\mathrm{a}}$ y $37^{\mathrm{a}}$ : a la pregunta $36^{\mathrm{a}}$, que corresponde a la lectura de la epístola, al lado derecho del altar, corresponde, según la respuesta, el desplazamiento a casa de Pilato; y la pregunta $37^{\mathrm{a}}$, cuando el sacerdote se movía al centro del altar, antes de pasar al lado izquierdo para la lectura del evangelio, es considerada como otro desplazamiento, desde la residencia de Pilato a la de Herodes. Si se trataba de buscar significado a los desplazamientos del sacerdote, hubiera sido más claro servirse de los dos desplazamientos, desde el lado de la epístola al centro del altar, y desde este punto al lado del evangelio. De esta forma se habría resaltado mejor el sentido de los dos trayectos. Pero ver o imaginar un itinerario mientras se lee la epístola... resulta demasiado imaginativo. 
El autor del Catecismo sobre la misa no dio con un significado claro que pudiera vincular al credo, y, en consecuencia, pasó directamente al ofertorio. Retirar el paño del cáliz es ocasión para proponer el despojo de las vestiduras de Cristo para ser azotado (pregunta 39a); nada dice de retirar la bolsa de los corporales, hecho que, por la misma lógica, podría tener el mismo sentido. El ofertorio propiamente dicho se vincula forzadamente con la flagelación, para mantener el orden de los hechos (pregunta $\left.40^{\mathrm{a}}\right)$, y, como a continuación correspondía la imposición de la corona de espinas, ésta la imagina en el hecho de cubrir el cáliz con la palia (pregunta $41^{\mathrm{a}}$ ). En este caso hay una patente contradicción con la pregunta $14^{a}$, que mostraba -en la sección primera- que la corona de espinas podía ser vista en la piadosa contemplación de los fieles en la coronilla del sacerdote; allí había un cierto paralelismo; pero en la propuesta de tapar el contenido del cáliz con la palia, hay que echar mucha imaginación para suponer entrevista la corona de espinas. Pero los hechos mandan, y es preciso plegarse a ellos, aunque se sacrifique la lógica, o lo que el propio texto había dicho antes. En cambio, resultaba clamoroso y fácil ver similitudes entre el lavatorio del sacerdote, y el gesto de exoneración de Pilato (pregunta $42^{\mathrm{a}}$ ).

Casi como un calco de lo que sucedía con el gloria, vuelve a ser presentado el prefacio, puesto que lo que en principio es un canto de exaltación de las maravillas obradas por Dios, es significado por el autor del Catecismo sobre la misa como el clamor que reclamaba la crucifixión de Jesús (pregunta 44a). Resulta desconcertante la formulación de la pregunta $45^{\mathrm{a}}$ sobre lo que se ha de considerar al "canon o santus". Aparecen como términos equivalentes, aunque no lo son ni podrían confundirse, incluso para los fieles que siempre tuvieron que asistir a la misa celebrada en latín. Pero la respuesta a tal pregunta valdría siempre para cualquier parte de la misa, precisamente por lo genérico de su formulación al hablar de la aceptación voluntaria de la pasión por parte de Jesús. De ahí que resulta previsible que no ofreciera problemas a ningún lector una pregunta tan desmañada.

Aparece de nuevo lo forzado de esta explicación en la pregunta $46^{\mathrm{a}}$, que se refiere al sonido de la campanilla. Ésta había sido introducida para llamar la atención sobre todo en la consagración y elevación para los muchos que no sabían latín. Pero aquí, a la conclusión del Sanctus. aprovechando la circunstancia de que se trata de un instrumento sonoro, da pie al autor de esta reflexión para hablar de las trompetas y bocinas que abrían paso a la comitiva de condenados a muerte. Cierto que se usó 
muchas veces, pero nada sabemos en el caso de Jesús. Posiblemente el autor fue inducido a ello por el hecho de que en las procesiones era frecuente que un trompetero abriera paso al cortejo devoto. Cuando se refiere a la elevación de la hostia se conduce al lector a la consideración de la erección de la cruz (pregunta $47^{\mathrm{a}}$ ). La siguiente pregunta alude al hecho de tomar el sacerdote la hostia consagrada con dos dedos, y la cifra le lleva a señalar a sus lectores que precisamente entre dos ladrones fue crucificado Jesús. Como se puede apreciar, el argumento no tiene demasiada consistencia. Y, a continuación, la elevación del cáliz apunta a considerar la sangre derramada por Cristo (pregunta $49^{\mathrm{a}}$ ).

Se alude expresamente al memento de difuntos (pregunta $50^{\mathrm{a}}$ ), a fin de que los fieles estimen la intercesión de Cristo por la humanidad; pero no deja de resultar llamativo que no se haya dicho nada anteriormente a propósito del memento de vivos. Una intercesión no está reñida precisamente con la otra. De nuevo se establece una vinculación numérica en la pregunta $51^{\mathrm{a}}$, al hacer el sacerdote cinco cruces, que son interpretadas como alusión a las cinco llagas tradicionales de Cristo. Resulta claro que se haga referencia al gesto, y no tanto a las palabras pronunciadas ${ }^{1}$, porque éstas resultaban menos inteligibles que lo que se efectuaba, que alguna vez podía ser visto de cerca y recordado.

Había que incluir en la reflexión de los lectores la alusión a la hiel y el vinagre, que conservan las páginas del evangelio; y ninguna oportunidad mejor que la segunda elevación conjunta, con la que concluye el canon: la hostia y el cáliz evocan la hiel y el vinagre, aunque no se vea fácilmente la conexión. La recitación del padrenuestro sugiere una vez más una ocasión de paralelismo numérico: todos los fieles sabían que está compuesto de siete peticiones: éstas llevan a pensar en las siete pala-

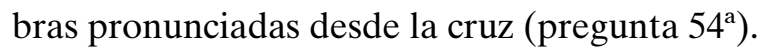

Absolutamente carente de sentido, ni siquiera figurado, es la respuesta que se propone en la pregunta $55^{\mathrm{a}}$, puesto que al hecho de la fracción de la hostia le asigna el sentido de "aquella voz que dio el Señor cuando murió". Ni con mucha imaginación se llega a percibir vinculación

\footnotetext{
${ }^{1}$ Se refiere a la parte del canon que comenzaba "Unde et memores...", en la que el sacerdote trazaba primero tres cruces sobre las especies consagradas, y luego otras dos, entre éstas y él mismo: "... hostiam + puram, hostiam + sanctam, hostiam + inmaculatam, Panem + sanctum vitae aeternae, et Calicem + salutis perpetuae". No se refiere a las otras cinco cruces que se trazaban al "per Ipsum...", pues antes de esta oración el Catecismo sobre la misa introduce otra pregunta sobre el golpe de pecho que se da el sacerdote, que corresponde al "Nobis quoque peccatoribus...".
} 
entre ambas cosas. Y de hecho, la respuesta fue alterada, como aparecerá más adelante.

El gesto de depositar una partícula de la hostia en el cáliz es sugerido para que sea entendido como el descenso de Cristo al limbo. El "agnus Dei" es contemplado como la conversión de muchos que intervinieron en la crucifixión; es más seguro que haga alusión a Lc 23, 48, que a los pasajes paralelos de Mt 27, 54; y Mc 15,39, centrados más directamente en las palabras del centurión que estaba al mando del piquete de ejecución.

La comunión del sacerdote (ni siquiera se menciona la de los fieles, como algo poco habitual, o algo carente de sentido) se identifica con la sepultura de Cristo; y volver a cubrir el cáliz es visto en el Catecismo sobre la misa como la losa que cerró el sepulcro de Cristo. Nada se dice en esta pregunta $59^{\mathrm{a}}$ que se refiera a la pregunta $17^{\mathrm{a}}$; pero no hay más remedio que recordar que en aquélla, se había dado a la patena el mismo significado de la losa que sellaba el sepulcro. Parece que no pasa nada por decir dos veces lo mismo, ni que sean dos objetos diversos (patena y paño) los que adquieren la misma significación.

Se asigna el significado de la resurrección de Cristo al hecho de que acuda al sacerdote desde el centro del altar al lado de la epístola para recitar la poscomunión (pregunta $60^{\mathrm{a}}$ ). Ésta es precedida del "Dominus vobiscum", entendido como el saludo de Cristo resucitado a sus apóstoles, que tiene, naturalmente, una cierta lógica evangélica. Sin embargo, como a continuación de la poscomunión vuelve a decir el sacerdote "Dominus vobiscum", esta segunda ocasión es contemplada como la ascensión (preguntas $61^{\mathrm{a}}$ y $63^{\mathrm{a}}$ ). Resulta forzado en extremo asignar dos sentidos bien diversos al mismo hecho, con una diferencia insignificante de tiempo entre una y otra ocasión; pero si esto lleva consigo una violencia en el significado, ésta aumenta cuando se recuerda que en la pregunta $34^{a}$, el "Dominus vobiscum" significaba el que Cristo volviera su rostro a Pedro tras sus negaciones. Evidentemente, se trataba de presentar la pasión, aunque para ello la lógica más elemental quedara sacrificada por el empleo de sentidos aleatorios.

Finalmente, la bendición evocaba la venida del Espíritu Santo (pregunta $64^{\mathrm{a}}$ ); y la lectura del prólogo del evangelio de Juan era contemplada como la predicación llevada a cabo por los apóstoles (pregunta $65^{\mathrm{a}}$ ). Sin solución de continuidad, y como si nada se hubiera alterado, las cuatro preguntas siguientes $\left(66^{\mathrm{a}}\right.$ a $\left.69^{\mathrm{a}}\right)$ volvían a ser las cuatro que, procedentes del segundo catecismo de Astete (denominado como Ripalda), cerra- 
ban el tema de la misa, es decir todo lo que debía conocerse sobre el primer mandamiento de la Iglesia. Tres preguntas iniciales, una larga interpolación y cuatro preguntas finales, que, como está anotado, articulaban el desarrollo del Catecismo sobre la misa.

Todo este cuestionario, simbólico, no exento de imaginación y en ocasiones puramente fantástico, nos sitúa ante el hecho de tratar de buscar un hilo conductor que diera sentido a la celebración de la misa. Ésta había perdido enteramente su capacidad de elocuencia por el hecho de que nada decía a los asistentes. Además de celebrarse en una lengua críptica, la complicación y acumulación de ceremonias habían llevado desde mucho tiempo atrás al desconocimiento más absoluto de lo que se realizaba en el altar. Había llegado a entenderse como un asunto entre el sacerdote y Dios, y en algunas explicaciones más cercanas a nuestros días que el Catecismo comentado, se desconocía enteramente la presencia de los fieles. Éstos acudían por la premura de la obligación, frecuentemente recordada, y, en el mejor de los casos, poseían un conocimiento global de sus grandes momentos (epístola, evangelio, consagración,...) pero no mucho más.

El tiempo de su permanencia en el templo era llenado con rezos y devociones que cada uno era libre de llevar a cabo, tuvieran o no relación con lo que se celebraba. En un momento determinado, en la segunda mitad del XVIII, alguien desconocido desarrolla una explicación "completa", al hilo de las diversas partes y ceremonias. Este anónimo y voluntarioso instructor tomó como hilo conductor el de la pasión de Cristo. De fondo, estaba la primera pregunta del Catecismo que nos ocupa:

\section{"P. ¿Qué es la Misa?}

R. Un Sacrificio que se hace de Cristo y una representación de su vida y muerte".

Con arreglo a este criterio, se buscan y retuercen significados, para ir proponiendo, paso a paso, la pasión de Cristo, pues lo que prima es su sacrificio. Más de fondo aún, como cimiento de toda la construcción, - -si bien no se menciona - está la concepción tridentina con su visión sacrificial. Precisamente la que era negada por los no católicos, que veían en la misa una evocación de la cena, cuando no una execrable idolatría llevada a cabo por parte católica ${ }^{2}$. Por tanto, la sintonía plena con el concilio de

\footnotetext{
${ }^{2}$ El Catecismo de Heidelberg señala en la pregunta $20^{\mathrm{a}}$ : "Qué diferencia hay entre la Cena del Señor y la Misa del Papismo? - La Cena del Señor nos testifica que nosotros
} 
Trento y su concepción de sacrificio, llevó a este autor ignoto a proponer la veta de la pasión como forma de seguir alegórica y simbólicamente las ceremonias 3 . Con la expresión "misterios" se englobaron tanto el sentido de la celebración y sus partes, como cada uno de los ritos, ceremonias, detalles y objetos empleados: todo tenía un significado y todo debía ser interpretado. Y puesto que la narración de la pasión lleva una secuencia temporal a medida que se desarrollaron los acontecimientos, había que establecer un paralelismo lo más ajustado posible entre los hechos que tuvieron lugar en Jerusalén, y cuanto se llevaba a cabo en la misa. Asignar o evocar posibles sentidos era tarea que permitía todas las licencias, con tal de mantener la correspondencia con el hilo conductor de la pasión. Y así se llevó a cabo.

El lector de este Catecismo sobre la misa podía así seguir el desarrollo de la misa ocupando su mente en las significaciones sugeridas, sin importar demasiado el sentido litúrgico, y menos aún, la procedencia de cada una de las ceremonias. Fue, sin dudarlo, una ayuda para la piedad de algunos creyentes, que se reafirmaron en la idea de la misa entendida como sacrificio; pero que, a la vez, llenaban el vacío de la incomprensión total con una explicación, que podía alimentar su devoción y su fe. En la época en que esto surgió -sin saber la fecha precisa de su origen y si hubo otras manifestaciones anteriores- al autor del Catecismo comentado no se le pasó por la imaginación que hubiera podido ser útil hacer una breve edición de una de las cuatro narraciones evangélicas de la pasión para que pudiera ser leída, dosificada o distribuida de tal manera que pudiera mostrar la pasión de Jesús a lo largo de la misa. La lectura directa de los libros bíblicos tenía sobre sí la prohibición y las cautelas formuladas también en Trento. En cambio, esta otra vía simbólica, alegórica, devocional, espiritual, tenía posibilidad de ser desarrollada.

Por otra parte, entre una lectura continua del texto de la pasión; o incluso entre una lectura distribuida u organizada del mismo, y una serie

tenemos remisión perfecta de todos nuestros pecados, por la virtud del único sacrificio de Cristo, que él mismo ofreció una vez en la cruz; y también que por el Espíritu Santo somos insertos en Cristo, el cual ahora, según su naturaleza humana, tan solamente está en los cielos a la diestra del Padre, donde quiere ser adorado por nosotros. Mas la Misa dice que los vivos ni los muertos no tienen remisión de pecados por la pasión sola de Cristo, si no es que aun ahora los sacerdotes ofrezcan por ellos al mismo Cristo; enseña también que Cristo está corporalmente presente en las especies del pan y del vino, y por tanto que en ellas ha de ser adorado. Así que el fundamento propio de la Misa no es otra cosa que una negación absoluta del único sacrificio y pasión de Jesucristo, y una abominable idolatría".

3 Conc. Tridentino, Sesión XXII, 17 sep. 1562): Doctrina de ss. Missae sacrificio (DS 1738ss); en particular, el cap. 8 de lo acordado en esta sesión señala que se expliquen a los fieles los misterios de su celebración. 
de preguntas breves, concisas, que no dejaban más que una interpretación como si fuera indiscutible, esta segunda forma tenía muchas posibilidades de salir triunfadora. De hecho es la que fue impresa y difundida. Y, aunque hoy no se puedan compartir la mayor parte de sus criterios, o muchos hayan de ser sometidos a revisión, es la que pasó a manos de los fieles. Que no se sepa nada de su autor, ni su fecha precisa, ni el lugar de publicación, resultan carencias que valdría la pena ver despejadas.

En cambio, con sorpresa, hay una pista de importancia que conviene seguir, cual es la de su difusión. No porque se conozca el número de ejemplares de la tirada; se ha salvado un ejemplar del Catecismo sobre la misa, que tengo por único, y no he tenido jamás noticia de otro. Pero todo no termina ahí.

\section{SeCción $3^{\text {a }}$ Pervivencia del teXto}

Desconozco absolutamente por qué extraños vericuetos la parte primera de este Catecismo sobre la misa ha sobrevivido al tiempo. Resulta difícil de explicar, porque hay un tremendo salto desde el testimonio primero conocido, de la segunda mitad del XVIII, hasta finales del XIX y comienzos del XX. No resulta posible reconstruir la cadena de testigos que han seguido repitiendo en una y otra ocasión este interrogatorio. Pero lo cierto es que ha sido así; o que alguien en las postrimerías del XIX entró en contacto con este Catecismo e hizo suyo lo que encontró escrito. Ahora bien, esta segunda hipótesis es menos probable, porque lo que se encuentra en las muestras más recientes tiene todos los visos de haber sufrido una lenta evolución, a base de retoques, que han alterado en cierto modo algunos detalles del contenido.

Dicho esto, es preciso dejar constancia de la existencia de dos "tradiciones", cada una de las cuales ha perpetuado el texto de forma diversa.

\section{La tradición primera}

Sustancialmente ha conservado el contenido de lo integrado en el Catecismo sobre la misa, aunque aparecerán los retoques.

Esta tradición admite una subdivisión: una sola muestra representa una de las variantes, y otras cuantas muestras representan la segunda variante. Los ejemplares son: 
a) Tradición primera, primera variante

Catecismo histórico por el Abad Claudio Fleury, corregido por la Inspección General de Instrucción Pública y por las Autoridades Eclesiásticas, Madrid, Isidoro Perales, 1917, 139-144.

b) Tradición primera, segunda variante

Catecismo histórico por el abate Fleury, Almería, Movimiento FAC, 1992. Reproduce con este título una edición lujosa, en dos volúmenes, de la que señala: Madrid, 1892; aunque omite la editorial, una paciente labor de cotejo me lleva a asegurar que se trata de una edición hecha por Saturnino Calleja.

Catecismo histórico por el abate Claudio Fleury. Edición Calleja. Corregida por siete teólogos presididos por un Ministro del Tribunal de la Rota nombrada por el Excmo. e Ilmo. Sr. Arzobispo-Obispo de Madrid-Alcalá con fecha 30 de Septiembre de 1893, Madrid, Saturnino Calleja, 1898.

Catecismo histórico por el abate Claudio Fleury. Única en España corregida por siete teólogos..., Madrid, Saturnino Calleja, s.a.

Catecismo histórico por el abate Claudio Fleury. Edición corregida por siete teólogos..., Madrid, Saturnino Calleja, s.a.

Catecismo histórico por el abate Claudio Fleury. Edición corregida por siete teólogos..., Madrid, Saturnino Calleja, s.a. (177 edición).

Catecismo histórico por el abate Claudio Fleury. Única en España corregida por siete teólogos..., Madrid, Saturnino Calleja, s.a.

Catecismo histórico por el abate Claudio Fleury. Única en España corregida por siete teólogos..., Madrid, Saturnino Calleja, s.a.

Son, pues, siete ejemplares salidos todos de las prensas de Calleja, que repiten el mismo texto, aunque tengo constancia de al menos otro ejemplar diverso, también de Calleja, que no incluye este interrogatorio.

Lo primero que hay que decir de todos los integrantes de la tradición primera es que en todos los casos, el interrogatorio que venía del que he denominado como Catecismo sobre la misa, aparece con un título invariable: "Excelencias y misterios de la misa". Este elemento, así como el contenido mismo, lo diferencian de la tradición segunda, que saldrá más adelante.

A la característica anterior del título se añade otra, no despreciable: han desaparecido siete preguntas de lo que contenía el texto primitivo, 
que no han dejado ni el vestigio de una frase confusa o vacía de sentido debida a un simple error de imprenta.

Las preguntas desaparecidas son:

- las preguntas $4^{\mathrm{a}}$ y $5^{\mathrm{a}}$, con el número y descripción de cuanto es necesario en la misa;

- la pregunta $15^{\text {a }}$, sobre el sentido de la cruz que adornaba la casulla;

- las preguntas $23^{\mathrm{a}}$ y $24^{\mathrm{a}}$, sobre el provecho propio y para el prójimo en la misa;

- la pregunta $46^{\mathrm{a}}$, sobre la campanilla que sonaba al rezo del sanctus;

- la pregunta 59a , cuando se cubre el cáliz al final de la misa.

Las dos primeras preguntas se pueden considerar innecesarias y parece bastante lógico que no se repitieran. La pregunta sobre la cruz de la casulla no difiere mucho de los sentidos artificiosos que se proponen para cada detalle, y no veo razón para su desaparición. Menos claro aún es encontrar una explicación para la supresión de las preguntas que se interesan por el bien espiritual que se puede obtener para uno mismo y para los demás con la asistencia a misa, que parecen muy adecuadas. Sorprende el silencio sobre la campanilla, que era uno de los elementos más destacados para los seglares asistentes, a quienes no llegaba el texto latino, pero sí el límpido sonido de la campanilla. La desaparición de la última pregunta puede tener una justificación, porque, como ha aparecido, era una especie de duplicación ilógica.

Esta tradición primera no ha dejado indemne el texto, y son numerosos los retoques. Hay dos, sin embargo, que son algo más que simples retoques, pues alteran totalmente el texto original, sustituido por otro nuevo. Así sucede en la pregunta $16^{\mathrm{a}}$ :

\section{TEXTO PRIMITIVO}

P. ¿Qué significa el Cáliz?

R. Aquel en que consagró el

Señor la noche de la Cena
Texto Alterado

P. ¿Qué significa el Cáliz?

R. El sepulcro donde pusieron a Cristo después de su muerte.

Lo mismo ocurre con la pregunta $55^{\mathrm{a}}$, reformada:

TEXTO PRIMITIVO

P. ¿Qué se considera al partir el Sacerdote la Hostia? R. Aquella voz que dio el Señor cuando murió.
TEXTO ALTERADO P. ¿Qué se considera al partir el Sacerdote la Hostia?

R. Cómo por la muerte de Cristo se separó su alma de su santísimo cuerpo. 
Otras muestras de las intervenciones sufridas, son, por ejemplo, que en la pregunta $30^{\mathrm{a}}$ se propone la contemplación de "la prisión y tropa con que le llevaron [a Cristo] los soldados"; esto se ha trastocado por "la pasión y el tropel...", que reiteran todas las muestras. Igualmente, los "rigurosos azotes" que se deben contemplar en el ofertorio, se han modificado siempre por "crueles azotes" (pregunta 40a). De la misma manera, en el ofertorio, al cubrir el cáliz se invitaba a imaginar la "agudísima y cruel" corona de espinas; pero tales adjetivos han sido suprimidos (pregunta $41^{\mathrm{a}}$ ). Y en la pregunta $43^{\mathrm{a}}$, el texto primero dirigía la atención a condolerse con Cristo puesto por Pilato a la consideración de todo el pueblo "en la Ventana de la casa de Pilato"; pero el detalle de la ventana no vuelve a aparecer.

En cuanto a las dos variantes de esta tradición primera, parece claro que tampoco se trata de simples erratas, que introdujeran cambios. Son pocos, pero dignos de consideración. Propongo un par de ejemplos. La lectura del primer evangelio era contemplada como "la Doctrina que nos enseñó Cristo, y el examen que de sus obras segunda vez hizo Pilato". Pero mientras consta así en las ediciones de Calleja, en la edición de Isidoro Perales no aparecen las palabras "segunda vez" (pregunta 38 $8^{\mathrm{a}}$ ). Otra muestra es que el texto primitivo establecía un paralelismo al coger el sacerdote la hostia consagrada con "dos" dedos, que evocaba la crucifixión entre "dos" ladrones; así aparece en la edición de Isidoro Perales, mientras que la de Calleja no subraya con tanta fuerza el paralelo de las cifras, al señalar que el sacerdote coge la hostia con "los dos" dedos (pregunta $48^{\mathrm{a}}$ ). Estos detalles, entre otros, permiten comprobar que ambos editores han seguido textos similares, pero que, alterados en algún eslabón de la tradición, evidencian que no ha habido una única vía de transmisión.

\section{La tradición segunda}

A propósito de esta tradición segunda, la afirmación inicial es que se trata de una variante, reelaborada, corregida y aumentada de cuanto representa la tradición primera. Sustancialmente sigue el mismo orden de las preguntas, pero se intercalan otras muchas, de forma que proporcionan en total casi el doble de extensión. Da la impresión de que quien la iniciara estimó que lo que había llegado hasta él en la tradición primera resultara incompleto, y que, por consiguiente, podía mejorarse, no sólo en cuanto a la cantidad de elementos formativos, sino también perfilando 
el estilo, la expresión y la redacción. Indudablemente esta tradición segunda es posterior, y se sustenta sobre la primera, aunque modifica cuanto estima conveniente con la supresión, pero sobre todo con la adición de nuevas preguntas. De esta forma, gana en extensión, y podría entreverse que la intención del desconocido redactor sea la de perfeccionar la enseñanza que había llegado hasta él. De ahí el notable incremento de preguntas que se insertan a lo largo de esta exposición, respecto a la tradición precedente. Mientras el Catecismo sobre la misa disponía de 69 preguntas, cuanto pasa a apéndice de otros catecismos, la tradición primera integra nada más que 59, en tanto que la tradición segunda, más explicativa, llega hasta las 96, es decir, casi el doble que la anterior. Es otra evidente diferencia entre ambas.

Con la particularidad de que todos los ejemplares que la incorporan son del catecismo de Ripalda (segundo Astete), y que no he encontrado ninguna muestra en las ediciones con el nombre de Astete, esta tradición segunda está representada en los siguientes ejemplares:

- Catecismo de la doctrina cristiana compuesto por el P. Jerónimo Ripalda, de la Compañía de Jesús, añadido por Juan Antonio de la Riva..., Madrid, Saturnino Calleja, s.a. (incompleta).

- Catecismo de la doctrina cristiana compuesto por el P. Jerónimo Ripalda, de la Compañía de Jesús, añadido por Juan Antonio de la Riva..., Sevilla, Sobrino de Izquierdo, 1924.

- P. Jerónimo Ripalda de la Compañía de Jesús. Catecismo de la doctrina cristiana, Madrid, Magisterio Español, s.a.

- Catecismo de la doctrina cristiana compuesto por el P. Jerónimo Ripalda, de la Compañía de Jesús, añadido por Juan Antonio de la Riva..., Madrid, Saturnino Calleja, s.a.

- Catecismo de la doctrina cristiana compuesto por el P. Jerónimo Ripalda, de la Compañía de Jesús, añadido por Juan Antonio de la Riva..., Aprobado por la autoridad eclesiástica en 1943 (o 1945?), Madrid, Saturnino Calleja, s.a.

- Catecismo de la doctrina cristiana compuesto por el P. Jerónimo Ripalda, de la Compañía de Jesús, añadido por Juan Antonio de la Riva..., Madrid, Hijos de Antonio Pérez, 1945.

- Catecismo Ripalda añadido por Juan Antonio de la Riva, Madrid, Hernando, 1954. 
Hay un dato que llama la atención: la tradición primera se encuentra en ejemplares del catecismo de Fleury, y la segunda en ejemplares del catecismo denominado de Ripalda (segundo Astete). Pero en ambos casos, aparecen catecismos publicados por Saturnino Calleja. Este editor no se tomó la molestia de unificar ambas tradiciones, sino que continuó con una para las ediciones del catecismo de Fleury, y con la otra para las ediciones del catecismo denominado como Ripalda. Resulta evidente que quien iniciara esta tradición segunda tenía a la vista algún ejemplar de la primera, y que lo que pretendió fue perfeccionar, completar y depurar lo que había llegado hasta él, particularmente con la inserción de nuevas y numerosas preguntas que tienden a matizar algunas de las afirmaciones que existían en el texto anterior. Con ello, la explicación de la misa resultaba aún más perfecta.

No hay forma de datar esta tradición segunda con precisión. El ejemplar más antiguo que la incluye carece de fecha. Podría ser de finales del siglo XIX, o principios del XX, y se ha extendido a lo largo de la primera mitad de este siglo.

La forma más sencilla de presentarla consiste en el empleo de la doble columna. En la primera (aunque se repita la tradición anterior), figurará la tradición primera; y en la otra columna, la segunda tradición, con sus añadidos, variantes, matices.

Una observación más: en la tradición segunda se han mantenido las tres primeras preguntas que procedían del segundo Astete (Ripalda) al comienzo; y han desaparecido las cuatro últimas que figuraron en el Catecismo sobre la misa, como se habían perdido también en la tradición primera.

Tradición primera

EXCELENCIAS

Y MISTERIOS DE LA MISA

P. ¿Qué cosa es Misa?
Tradición segunda

SIGNIFICACIÓN, GRANDEZA Y EXCELENCIAS DEL SANTO SACRIFICIO DE LA MISA.

EXPLICACIÓN DE LAS SAGRADAS CEREMONIAS DE LA MISMA Y TODOS LOS OBJETOS QUE SIRVEN PARA CELEBRARLA

P. ¿Qué cosa es Misa? 
R. Un Sacrificio que se hace de Cristo y una representación de su vida y muerte.

P. ¿A quién se hace este sacrificio?

R. Al Eterno Padre.

P. ¿Para qué?

R. Para tres fines: para darle gracias, satisfacerle y pedirle beneficios.
R. Un Sacrificio que se hace de Cristo y una representación de su vida y muerte.

P. ¿A quién se hace este Divino Sacrificio?

R. Al Eterno Padre.

P. ¿Para qué?

R. Para tres fines: para darle gracias, para satisfacerle y para pedirle beneficios.

P. Cómo debemos asistir al santo sacrificio de la Misa?

R. Con la mayor modestia, veneración y respeto, y con todo el aseo y decencia que nos permitan nuestros medios.

P. ¿Pues por qué se exigen tales condiciones?

R. Porque la misa es el acto más perfecto y más santo de la Religión cristiana, única verdadera.

P. ¿Qué razón hay para que le consideremos tan perfecto?

R. La de que la misa es la más viva representación de la santísima vida de Nuestro Señor Jesucristo y de su pasión y muerte.

P. ¿A quién representa al Sacerdote?

R. Al mismo Jesucristo.

P. $¿$ Y el que le ayuda a celebrar la misa?

R. A los ángeles que asisten a Jesucristo. 
P. ¿Qué significa el Amito?

R. El velo con que vendaron a Cristo los ojos y su santísimo rostro

P. ¿Y el alba?

R. Aquella vestidura blanca que por escarnio pusieron a Cristo en casa de Herodes.

P. ¿Qué significa el cíngulo?

R. La soga con que fue atado en el Huerto.

P. ¿Y el manípulo?

R. Significa los cordeles con que fue amarrado a la columna.

P. ¿Y la Estola?

R. Aquella soga con que Cristo fue llevado a crucificar, tirando de ella, puesta al cuello.

P. La casulla, ¿qué significa?

R. La púrpura vieja y rota que por escarnio vistieron a Cristo en casa de Pilato.
P. ¿Qué significa el amito?

R. El velo con el que los judíos cubrieron la cara de nuestro Redentor para hacer burla de Él, exigiéndole que adivinase quién le había maltratado.

P. ¿Qué representa el alba?

R. La vestidura blanca que $\mathrm{He}-$ rodes mandó poner a Jesucristo, para hacer burla de Él tratándole de loco.

P. ¿Qué significa el cíngulo

R. La cuerda con que ataron a Jesucristo cuando le prendieron en el huerto de Getsemaní.

P. ¿Y el manípulo?

R. La cuerda con que le ataron a la columna.

P. ¿Qué representa la estola?

R. La soga que llevó al cuello cuando fue al Calvario con la cruz a cuestas.

P. ¿Qué nos recuerda la casulla?

R. El vestido de púrpura viejo y roto que pusieron a Jesucristo, para hacer burla de Él, llamándole rey de los judíos.

P. ¿Significa algo el color de los ornamentos con que el Sacerdote celebra la misa?

R. Sí, cada color tiene su significación especial.

P. ¿Qué significa el color blanco? 
R. Pureza, y por eso se usa en las festividades de los Santos, Confesores y Vírgenes.

P. ¿Y el encarnado?

R. Significa caridad, y por eso se hace uso de él en las fiestas de los Apóstoles y de los Mártires.

P. ¿Y el verde?

R. Significa esperanza, y por eso se usa en las fiestas en que más especialmente se nos hace la promesa de los bienes eternos.

P. ¿Y el morado?

R. Significa tristeza, y se usa en los días de ayuno y penitencia.

P. ¿Y el negro?

P. ¿En qué se nos da a entender la corona de Espinas que pusieron a Cristo?

R. En la que lleva el sacerdote figurada en su propia cabeza.

P. ¿Qué significa el Cáliz?

R. El sepulcro donde pusieron a Cristo después de su muerte.

P. ¿Y la patena?

R. Es señal de luto y de quebranto, y por eso se usa cuando se hace conmemoración de los difuntos.

P. ¿Qué representa el cáliz?

R. El sepulcro en que fue depositado el cuerpo de Jesucristo.

R. La losa que pusieron los judíos sobre el sepulcro de Cristo.

P. ¿Y la hostia sin consagrar?

R. Aquel pan que Cristo consagró en la noche de la Cena.

P. ¿Y la patena?

R. La piedra o losa que sirvió para cerrar el sepulcro de nuestro Salvador. [Sevilla, 1924 pone "fosa"].

P. ¿Qué representa la hostia y el vino sin consagrar? 
R. El pan y el vino que Jesucristo convirtió en su cuerpo y en su sangre en la noche de la última cena, y que después repartió entre todos los Apóstoles, encargándoles que hiciesen lo mismo en conmemoración suya.

P. El paño o velo que cubre el cáliz y los corporales, ¿qué significa?

$\mathrm{R}$. Los lienzos en que fue envuelto el cuerpo difunto de Cristo.

P. ¿Qué significa el altar con la Cruz? R. El monte Calvario

P. ¿Las velas encendidas?

R. La humildad, devoción, reverencia y fervor con que debemos asistir al santo sacrificio de la misa.
P. ¿Qué significan los corporales?

R. La sábana limpia y nueva en que José de Arimatea envolvió el cuerpo de Nuestro Señor Jesucristo para llevarle al sepulcro.

P. ¿Qué significa el altar?

R. El monte Calvario.

P. ¿Y la cruz que debe haber precisamente en el altar en que se dice la misa?

R. La viva imagen de Nuestro Señor Jesucristo, cuya memoria se renueva por el santo sacrificio

P. ¿Qué significan las luces que se ponen sobre el altar?

$\mathrm{R}$. Las luces de la fe, sin las cuales no podemos salvarnos ni creer los misterios de nuestra sacrosanta Religión, y también las señales del divino gozo y de la santa alegría de que debemos estar poseídos en presencia del Señor.

P. ¿Qué partes tiene la misa?

R. Dos partes principales: la primera comprende desde el principio hasta el Ofertorio, 
y la segunda desde el ofertorio hasta el fin.

P. ¿Qué debemos hacer para oír misa con gran provecho de nuestra alma?

R. Fijarnos bien en el significado de cada una de sus ceremonias y considerar bien lo que representan.

P. ¿Podremos, según el orden de la misa, considerar mientras el Sacerdote sale al Altar?

R. Sí, y con provecho de nuestras almas.

P. Pues siendo así, decidme, ¿qué debemos considerar mientras el sacerdote sale al altar?

R. La última cena, en que fue instituido tan alto y divino sacrificio.

P. ¿Y cuando llega al altar?

R. La presteza y diligencia con que Cristo fue a orar al Huerto con los Apóstoles.

P. ¿Y el principio de la misa?

$\mathrm{R}$. La oración que tres veces hizo en el Huerto.

P. ¿Qué debemos considerar en la confesión?
P. ¿Qué debemos traer a nuestra memoria mientras el Sacerdote se dirige al altar?

R. La última cena, en la cual fue instituido ese divino sacrificio.

P. ¿Y luego que ha llegado al altar?

R. La prontitud y diligencia con que fue a orar al huerto de Getsemaní, en que lo prendieron.

P. ¿Qué debemos considerar cuando principia la misa?

R. La oración que dirigió tres veces al eterno Padre en el mismo huerto.

P. ¿Qué debemos considerar durante la confesión? 
R. Las agonías y sudor de sangre que padeció Cristo.

P. ¿Al besar el altar el sacerdote?

R. Aquel falso beso que dio Judas a Cristo para que los judíos, conociéndole, le prendiesen.

P. Al ir el sacerdote al lado de la Epístola, qué debe considerarse?

R. Considerar la pasión de Cristo y el tropel con que le llevaron los soldados.

P. ¿Y el introito de la misa?

R. El examen que hizo Anás del mismo Cristo.
R. Las agonías y sudores de sangre que padeció Jesucristo.

P. Cuando el Sacerdote besa el altar, ¿qué debemos tener presente?

R. El beso que traidoramente dio Judas a Jesucristo en el huerto para que le conocieran y pudieran prenderle.

P. Cuando al Sacerdote se dirige al lado de la Epístola, ¿qué hemos de considerar?

R. La pasión de Jesucristo, y la gente armada que le prendió y le condujo a casa de Anás. [Se mantiene "pasión" en vez de "prisión"].

P. ¿Qué es el Introito?

R. Una oración compuesta de diversos pasajes de los Salmos.

P. ¿Qué deben hacer los fieles mientras el Sacerdote recita esta oración?

R. Humillarse ante Dios, reconocer sus pecados y arrepentirse de ellos.

P. Respecto de la Pasión, ¿qué representa el Introito?

R. Las palabras que Anás dirigió a Cristo.

P. ¿Qué deben hacer los fieles siempre que el Sacerdote dice Oremus?

R. Fijar más y más su atención en el santo sacrificio y unir sus oraciones a las del Sacerdote. 
P. ¿Qué se ha de considerar en los kyries?

R. Las tres negaciones de San Pedro.

P. ¿Al gloria?

R. La alegría que los judíos tenían de las penas y tormentos que padecía Cristo nuestro bien.

P. ¿Y al Dominus vobiscum?

R. Cuando Cristo volvió su divino rostro a San Pedro.

P. En las primeras oraciones, ¿qué hemos de considerar?

R. Las acusaciones, afrentas y desprecios, bofetadas y salivas que recibió Cristo en casa de Caifás.
P. ¿Qué significan las palabras Kyrie y Christe eleison, que el sacerdote y el que le ayuda repiten nueve veces?

R. El ruego que dirige a cada una de las tres personas de la Santísima Trinidad para que tengan piedad de nosotros.

P. ¿Qué representan los Kyries relativamente a la Pasión?

R. Las tres negaciones de San Pedro respecto de Jesús.

P. ¿Qué es el Gloria in excelsis?

R. Un cántico de acción de gracias, cuyas primeras palabras son las que los ángeles dijeron cuando nació nuestro Señor Jesucristo.

P. Respecto a la pasión, ¿qué representa el Gloria in excelsis?

R. La alegría de los judíos al ver los padecimientos de nuestro Señor Jesucristo.

P. ¿Qué significa la Colecta?

R. Varias cosas, pero en especial el hecho de reunir el Sacerdote todos los votos de los fieles para presentarlos con los suyos al Padre Eterno.

P. ¿Qué debemos recordar durante las primeras oraciones de la misa?

R. Las injurias, afrentas, desprecios y malos tratamientos de que fue objeto Jesucristo en casa de Caifás. 
P. ¿Y cuando se lee la Epístola?

R. Considerar cuando Cristo fue llevado a casa de Pilato.

P. ¿Y al ir al medio del altar?

R. Cuando Cristo fue llevado desde casa de Pilato a la de Herodes.
P. ¿Qué es la Epístola?

R. La lectura de una parte de la Sagrada Escritura.

P. ¿Cómo debe escucharse?

R. Con extremada atención, pidiendo gracia a Dios para practicar lo que en ella se contiene.

P. ¿Qué debemos recordar con la lectura de la Epístola?

R. Que Cristo fue llevado a casa de Pilato.

P. Cuando el Sacerdote vuelve al medio del altar después de haber leído la Epístola, ¿qué debemos considerar?

R. Que Cristo fue llevado desde la casa de Pilato a la de Herodes.

P. ¿Qué es el Gradual?

R. Una oración que el Sacerdote recita, o que se canta después de la Epístola, y sirve como preparación para el Evangelio.

P. ¿Qué sigue inmediatamente al Gradual?

R. Desde Pascua de Resurrección hasta Septuagésima (quince días antes del domingo de Carnaval), la antífona Aleluya, en señal de alegría; y desde Septuagésima hasta Pascua algunos versículos de un salmo de penitencia, en señal de dolor y de arrepentimiento.

P. ¿Por qué el Sacerdote y los fieles se persignan al comen- 
P. ¿Qué hemos de considerar cuando se lee el primer evangelio?

R. La doctrina que nos enseñó Jesucristo, y el examen que de sus obras segunda vez hizo Pilato. zar la lectura del primer Evangelio?

R. Para protestar que no renegarán jamás de las verdades que contiene, que las confesarán siempre y que las tendrán toda la vida grabadas en su corazón.

P. ¿Qué debemos tener presente durante la lectura del primer Evangelio?

R. La santa doctrina de Jesucristo y el examen que de sus actos hizo Pilato por segunda vez.

P. ¿Por qué los que llegan tarde a la Iglesia creen que han oído misa si no se ha pasado todavía el Misal al lado del Evangelio?

R. Porque la Misa propiamente dicha empieza inmediatamente después del Credo, o sea con el Ofertorio.

P. Pero, ¿qué deben hacer los cristianos celosos del cumplimiento de sus deberes para con Dios?

R. Estar en la Iglesia antes de que el Sacerdote salga de la sacristía.

P. ¿Qué es el Símbolo, que comienza con las palabras Credo in unum Deum?

R. Esta oración o profesión de fe que se reza o canta en la misa no es otra cosa que el Credo que hemos aprendido en este Catecismo. 
P. ¿Qué es el Ofertorio?

R. Una ceremonia por virtud de la cual el Sacerdote ofrece a Dios la Hostia y el Cáliz.

P. ¿Y cuando se descubre el cáliz?

R. Considerar cómo Cristo fue despojado de sus vestiduras para ser amarrado a la columna y rigurosamente azotado.

P. ¿Y al ofertorio?

R. Aquellos crueles azotes que impíamente descargaron sobre el venerabilísimo cuerpo de Jesús.

P. Al cubrir el sacerdote el cáliz, ¿qué se ha de considerar?

R. Cuando pusieron la corona de espinas en la santísima cabeza de Cristo.

P. ¿Y al lavarse las manos?

P. ¿Qué representa el Ofertorio respecto de la Pasión?

R. Los crueles azotes que los judíos dieron a Cristo.

P. Cuando el Sacerdote cubre el Cáliz, ¿qué debemos considerar?

R. Que los judíos pusieron una corona de espinas en la sagrada cabeza de Jesucristo.

P. ¿Qué representa en la misa esa corona de espinas?

R. La que está en la corona que el celebrante lleva figurada en la cabeza.

P. ¿Qué es lo que reza el Sacerdote durante el lavatorio?

R. Un Salmo, en virtud del cual pide a Dios pureza para ofrecer el santo sacrificio

R. El lavatorio de Pilato.

P. ¿Y qué debemos recordar mientras el Sacerdote se lava los dedos?

R. El lavatorio de Pilato.

P. ¿Y al Orate fratres?

R. Considerar cómo Cristo fue pues-

P. ¿Qué debe traer a nuestra memoria el Orate fratres? to a la vista de todo el pueblo y dijo Pilato: Ecce Homo.

R. La presentación que Pilato hizo de Jesucristo a todo el 
P. ¿Qué se considera al Prefacio?

R. Cómo el vil pueblo, no contento con lo que Cristo había padecido, gritó pidiendo que le crucificasen.

P. ¿Y al Santus y Canon?

R. La humildad con que Cristo cargó sobre sus benditos hombros la pesada cruz que simbolizaba nuestras culpas pueblo judío diciendo Ecce Homo.

P. ¿Qué es el Prefacio?

R. Una tierna y patética oración que termina con estas palabras: Sanctus, Sanctus, Sanctus

P. ¿Qué debemos considerar con motivo del Prefacio?

R. Que el pueblo judío, no satisfecho con lo que había hecho sufrir a Cristo nuestro Señor, gritó pidiendo que le crucificaran.

P. ¿Qué es el Canon?

R. La regla fija e invariable para celebrar la misa, por virtud de la cual el Sacerdote ruega por el Papa, por el Obispo de la Diócesis, por el Rey, por todos los fieles cristianos, por los que se hallan presenten y por aquellos por quienes desea rogar en particular.

P. ¿Qué hemos de considerar en el Canon?

R. La humildad con que Jesús cargó sobre sus hombros la pesada Cruz, que representaba nuestros pecados.

P. ¿En qué consiste la Consagración?

R. En el hecho inefable de que, por las palabras del Sacerdote, se convierten las especies de pan y de vino en el Cuerpo, sangre, alma y divinidad de nuestro Señor Jesucristo. 
P. ¿Qué deben hacer los fieles cuando el Sacerdote eleva la Hostia y el Cáliz?

R. Adorar a Dios con profundo respeto, dándose golpes de pecho, y pedirle misericordia.

P. ¿Y al tocar la Campanilla tres veces?

R. Considerar el ruido de roncas Trompetas y Tambores, y los Pregones que decían llevando a Cristo a crucificar.

P. ¿Qué se ha de considerar a la elevación de la hostia?

R. Cómo Cristo, después de crucificado, fue levantado en alto a la vista de todo el pueblo.

P. ¿Y al tomar el sacerdote la hostia con los dedos?

R. El haber sido crucificado Cristo en medio de los ladrones.

P. Y al elevar el cáliz, ¿qué se ha de contemplar?

R. A Cristo nuestro Señor derramando por nosotros su sangre en el árbol de la cruz.

P. ¿Qué hemos de considerar al memento por los difuntos?

P. ¿Qué debemos considerar durante la elevación de la Hostia?

R. Que Jesucristo, después de crucificado, fue levantado en lato a la vista de todo el pueblo.

P. ¿Indica algo el hecho de que el Sacerdote toma la Hostia con los dedos?

R. Nos recuerda que Jesucristo fue crucificado en medio de dos ladrones.

P. ¿Qué debemos tener presente cuando el Sacerdote eleva el Cáliz?

R. Que Cristo, nuestro bien, derramó su sangre por salvarnos.

P. ¿Qué representa el Memento o recuerdo de los difuntos?

R. Cómo Cristo rogó a su eterno Padre por el género humano. 
P. $¿ \mathrm{Y}$ al hacer el Sacerdote las cinco cruces sobre el cáliz y la hostia?

R. Se han de considerar las cinco llagas que recibió el Señor en manos, pies y costado.

P. ¿Y cuando se da un golpe en el pecho?

R. Cómo Cristo rogó por los que le crucificaron.

P. ¿Y al alzar la hostia con el cáliz?

R. Considerar la hiel y el vinagre que dieron a Cristo.

P. ¿Y al decir el Pater noster?

R. Se considera aquellas siete palabras que habló Cristo en la cruz.
R. La oración que Jesucristo hizo a su divino Padre en favor del género humano.

P. ¿Por qué hace el Sacerdote cinco cruces sobre la Hostia y el Cáliz?

R. Para que recordemos las heridas o llagas que nuestro Señor recibió en manos, pies y costado.

P. ¿Qué debemos considerar cuando el Sacerdote se da un golpe en el pecho?

R. Que Jesucristo llevó su amor y caridad hasta el punto de rogar por aquellos que le crucificaron.

P. ¿Qué debemos traer a nuestra memoria cuando el Sacerdote levanta la Hostia con el Cáliz?

R. Lo que sufrió nuestro Señor Jesucristo cuando le dieron a beber hiel y vinagre.

P. ¿Cuál es la oración más importante que el Sacerdote reza después de la Consagración?

R. El Padre nuestro, o sea la oración que el mismo Jesucristo compuso a petición de los Apóstoles.

P. ¿Qué debemos recordar cuando el Sacerdote dice esta oración?

R. Las siete palabras que Jesucristo dijo en la Cruz. 
P. ¿Qué se considera al partir el sacerdote la hostia?

R. Cómo por la muerte de Cristo se separó su alma de su santísimo cuerpo.

P. ¿Al poner una parte de la hostia dentro del cáliz?

R. El descendimiento de Cristo al Limbo donde se hallaban los Santos Padres.

P. Al decir el sacerdote tres veces Agnus Dei, ¿qué se considera?

R. La conversión de muchos de los que crucificaron a Cristo.
P. ¿Qué hemos de considerar cuando el Sacerdote parte la Hostia?

R. Que por la muerte de Jesucristo se separó su alma de su santísimo cuerpo.

P. ¿Qué debemos recordar cuando el Sacerdote pone una parte de la Hostia dentro del Cáliz?

R. El descendimiento de Cristo al seno de Abraham, donde se hallaban los Santos Padres esperando el santo advenimiento.

P. ¿Qué es el Agnus Dei?

R. Una oración que el Sacerdote repite tres veces preparándose de este modo para la comunión?

P. ¿Cómo termina esta oración?

R. Con las palabras en que pedimos a Dios que nos de la paz, es decir, una conciencia tranquila y la paz temporal.

P. ¿Qué debemos considerar cuando el Sacerdote reza el Agnus Dei?

R. La conversión de muchos de los que contribuyeron a que Jesús fuese crucificado.

P. ¿Qué cosa es Comunión?

R. Un manjar espiritual que sustenta el alma y le da vida eterna. Al comulgar el Sacerdote y los que se hallan convenientemente preparados, reciben el cuerpo, la san- 
P. ¿Y cuando el sacerdote comulga?

R. El entierro que los santos varones hicieron al cuerpo difunto de Cristo.

P. Al ir el sacerdote al lado de la Epístola, ¿qué significa?

R. La resurrección de Jesucristo. P. ¿Y al Dominus vobiscum?

R. La aparición de Jesucristo a sus apóstoles.

P. A las últimas oraciones, ¿qué se ha de considerar?

R. El tiempo que estuvo Cristo en esta vida con sus apóstoles después de resucitado. gre, el alma y la divinidad de nuestro Señor Jesucristo, es decir, al mismo Cristo, Dios y hombre todo entero.

P. ¿Qué debemos considerar mientras el Sacerdote comulga?

R. Que Jesucristo fue enterrado por José de Arimatea en un sepulcro nuevo.

P. ¿Qué deben hacer los que asisten a la misa y no comulgan?

R. Humillarse ante Dios, unir su corazón a Jesucristo y pedirle la gracia necesaria para comulgar dignamente cuando les llegue el caso de cumplir con este precepto.

P. ¿Qué es la acción de gracias?

R. Una oración que dice el Sacerdote después de haber comulgado.

P. Cuando el Sacerdote va al lado de la Epístola, ¿qué debemos considerar?

R. La resurrección de Jesucristo.

P. ¿Y cuando dice el Dominus vobiscum algunos momentos después?

R. Las diversas veces que Jesucristo se apareció a los Apóstoles.

P. ¿Sobre qué hemos de meditar mientras el Sacerdote dice las últimas oraciones?

R. El tiempo que estuvo Jesús en el mundo después de resucitado. 
P. ¿Y al último Dominus vobiscum?

R. La ascensión del Señor.

P. ¿Qué se considera cuando el sacerdote echa la bendición?

R. La venida del Espíritu Santo sobre el Colegio apostólico

P. ¿Y al último Evangelio?

R. La predicación que de Jesucristo y sus admirables doctrinas hicieron por todo el mundo los apóstoles.

P. ¿Qué hemos de recordar cuando el Sacerdote dice la última vez Dominus vobiscum?

R. La Ascensión del Señor.

P. ¿Qué hemos de considerar cuando el Sacerdote bendice a los fieles en el nombre del Padre y del Hijo y del Espíritu Santo?

R. La venida del Espíritu Santo sobre los Apóstoles.

P. ¿Cómo hemos de recibir esta bendición?

R. De rodillas y con el debido fervor, devoción y humildad, para que en nosotros produzca lo que de ella debemos esperar.

P. ¿Termina con esto la Misa?

R. Sí; pero después de ella el Sacerdote lee una parte del Evangelio.

P. ¿Qué debemos hacer durante su lectura?

R. Recordar las admirables enseñanzas de Jesucristo, predicadas por los Apóstoles en todo el mundo, y dar gracias a Dios por haberse dignado hacerse hombre como nosotros para salvarnos.

P. ¿Cómo debemos salir de la Iglesia después de haber oído misa?

R. Con el mayor recogimiento, pues hemos asistido a una serie de ceremonias, todas misteriosas, que nos recuerdan los inmensos beneficios que debemos a Dios. 
Hasta aquí la exposición contrastada de las dos tradiciones

Además del cambio de título, significativo, no se puede dejar de considerar que, con un sentido didáctico, el redactor de la segunda tradición no da por conocida cada parte de la misa, e introduce unas preguntas sobre lo que son. Una vez hecho esto, retoma el hilo para aplicar cada parte a la consideración o meditación de la pasión. La exposición de esta tradición segunda evidencia un notable deseo de perfección, de no dejar nada sin aclarar, de completar cuanto venía de la tradición anterior. Aunque sólo fuera por este detalle, hay que concluir que resulta claramente posterior, y que se construye sobre todo lo precedente, desbordándolo.

Los criterios litúrgicos de estas dos tradiciones, no difieren gran cosa entre sí; como tampoco lo hacen en gran medida de cuanto venía desde la mitad del siglo XVIII, en el Catecismo sobre la misa. Poco o nada habían cambiado; el que en una u otra versión se remarque o silencie un aspecto particular, nada cambia de fondo.

Además de la labor didáctica que ha asumido el autor de la tradición segunda, hay una función moral, para dejar su explicación lo más completa posible. Por eso es destacable la pregunta que se interesa por aquellos que llegan tarde a misa, sobre si han visto o no pasar el misal al lado del evangelio, "porque la Misa propiamente dicha empieza inmediatamente después del Credo". Todo lo anterior son prolegónemos, adornos ceremoniales, u ornamentación litúrgica, que está bien, pero que no resulta indispensable. La palabra de Dios se ha difuminado, puesto que el acento sacrificial es lo único destacable en la misa; por allí iban los acentos morales y litúrgicos, al unísono.

Esto, lógicamente, conecta con la otra pregunta que figura casi al principio, cuando se interesa por las partes en que se articula la misa: "Dos partes principales: la primera comprende desde el principio hasta el Ofertorio, y la segunda desde el Ofertorio hasta el fin". A la vista de lo afirmado sobre la misa propiamente dicha, no hay más remedio que convenir que las dos partes "principales" no lo son precisamente por la importancia que pueda tener en sí misma cada una, sino por la diferenciación entre ellas, y por la sucesión cronológica. Pero nada más. Como se decía, con cierta sorna, en los tiempos en que estos criterios seguían vigentes, antes de la revisión y renovación actual, la primera parte constituía el "nodo", el previo noticiario cinematográfico, mientras que la segunda era en verdad la película; ésta había sido vista, aunque uno se perdiera el "nodo". 
Para el autor-corrector de la segunda tradición no hay duda que lo escrito es un apéndice que hay que añadir al catecismo: lo muestra cuando trata de explicar qué es el "símbolo", empleando la expresión menos usual, y para dejarlo claro a sus lectores asegura que es lo misma que "el Credo que hemos aprendido en este Catecismo".

No quiero dejar de notar el escasísimo papel que representan los fieles en toda esta consideración. Es claro que este tipo de explicación, en las dos tradiciones, como anteriormente en el Catecismo sobre la misa, tiene como destinatarios y lectores a los fieles. Pero al ir proponiendo parte a parte, se les invita a éstos a una consideración o meditación sobre lo que hace el sacerdote, con indiscutible protagonismo. Los fieles son los sujetos activos de esta meditación; pero no son sujetos activos del desarrollo de la misa. Salen, en efecto, el ministro o ayudante; también se hace en la segunda tradición una reflexión sobre los que comulgan, y los que no lo hacen. Pero su papel, secundario, queda obnubilado por lo que el celebrante lleva ritualmente a cabo, que es lo fundamental. Y en ese papel menguado de los asistentes, es evidente que el sentido comunitario está ausente. Lo que cada fiel ha de hacer es considerar, meditar, tener en cuenta, o recordar lo que se le propone, pero siempre a título privado. La idea de comunidad está totalmente ausente, aunque haya referencias plurales ("Cristo entregó su vida por los hombres", "por nosotros", "por todos...”), son del todo inoperantes.

Los testimonios presentados son bienintencionados esfuerzos por llenar la absoluta pasividad de los fieles, presentes en una celebración que nada les decía al llevarse a cabo en una lengua extraña. Y es justo reconocer que la intención, salvable, cumplía de principio a fin su cometido, para tener ocupado y en oración al fiel que seguía la misa con este guión en sus manos -sea en la versión que sea-. No deja de resultar chocante, cuando no mordaz, la recomendación que se hace a los lectores cuando llega el momento de la epístola, pues se les aconseja, nada menos que "escuchen... con extremada atención, pidiendo gracia a Dios para practicar lo que en ella se contiene". Y se aduce el motivo en la pregunta anterior, cuando se asegura que la epístola "es una parte de la Sagrada Escritura" (del evangelio no se dice lo mismo). Pero, con el aprecio que se hacía de la biblia en los tiempos en que estas propuestas estuvieron vigentes, daba lo mismo que se tratara de partes de la Escritura, o de textos de la Eneida.

La liturgia constituía un entramado de misteriosas ceremonias, envueltas en el arcano, que eran desarrolladas con una fijeza ritual, tuvie- 
ran o no sentido desde el punto histórico o celebrativo. Mientras, al pueblo había que aconsejarle algún tipo de devociones (rosarios, vía crucis, oraciones en general), o algunas propuestas como las presentes, para que tuvieran ocupadas sus mentes. En este caso, desde el punto de vista de la pasión, pues el subrayado del sacrificio realzaba de modo superlativo esta consideración. 